\title{
BAD HABITS AND THEIR IMPACT ON STUDENTS' HEALTH
}

10.36740/WLek202011111

\author{
Grygoriy P.Griban ${ }^{1}$, Mykhailo S. Myroshnychenko ${ }^{2}$, Pavlo P.Tkachenko ${ }^{3}$, Tetiana Ye. Yavorska ${ }^{1}$, \\ Nataliia Ye. Kolesnyk ${ }^{1}$, Inesa V. Novitska ${ }^{1}$, Igor A. Verbovskyi ${ }^{1}$ \\ 'ZHYTOMYR IVAN FRANKO STATE UNIVERSITY, ZHYTOMYR, UKRAINE \\ ${ }^{2}$ KHARKIV NATIONAL MEDICAL UNIVERSITY, KHARKIV, UKRAINE \\ ${ }^{3}$ POLISSIA NATIONAL UNIVERSITY, ZHYTOMYR, UKRAINE
}

\begin{abstract}
The aim: Is to investigate the bad habits of the students of higher education institutions and their impact on health. Materials and methods: The research of the students' bad habits was conducted at Polissia National University and Zhytomyr Ivan Franko State University in $2014-2019$. 647 students of different specialties between the ages of 17 and 23 were interviewed. The research methods included theoretical methods (the analysis and generalization of literary sources, the evaluation of the quality of students' performance in classes, the study and analysis of the medical records of students); empirical methods (pedagogical observations, questionnaires, surveys); the methods of mathematical statistics.

Results:Thestudyfoundthat $32.4 \%$ ofmalestudentsand $14.9 \%$ offemalestudentssmoke. Itwas definedthatmalestudents of thespecialeducationdepartment smokethe most-37.7\%;32.5\% and $27.1 \%$ of the male students of the main and sports departments smoke respectively. Among female students, $18.4 \%$ of the students of the sports department, $14.6 \%$-ofthe main department and $13.4 \%$-of the special department smoke. The study determined that $2.7 \%$ of both male and female students of the first year of study drink alcohol almost every day, 3.7\%-2-3 times a week, 18.2\%-once a week, 66.0\%-only on holidays. Besides, the research indicated that some students use drugs. It was found that the students know that smoking, alcohol, and drugs are harmful but cannot or do not want to get rid of these bad habits.

Conclusions: The study established that the environment of students is unfavorable for the activation of the healthy lifestyle components; it contributes to the spread of bad habits, the consequences of which students do not realize fully. Many students do not have a need to take care of their own health.
\end{abstract}

KEY WORDS: bad habits, health, physical education, students

Wiad Lek. 2020;73(11):2386-2395

\section{INTRODUCTION}

Taking account of the removal of the discipline "Physical Education" from the list of compulsory disciplines of Ukrainian higher education institutions and reducing the number of academic hours devoted to mastering the program material in this discipline, there is a need to investigate the ways ensuring the efficiency of the students' physical education in accordance with the modern standards of higher education. This becomes especially relevant in a situation of constant deterioration of the psychophysical condition of young students, as evidenced by the results of numerous studies $[1,2,3]$. Conducting various forms of physical education should ensure the engagement of physical culture in the lifestyle of students in order to achieve the optimal level of their physical activity and health. Therefore, many studies have been conducted recently to investigate the problem of improving the content of physical education in extracurricular activities $[4,5,6]$. The need to find innovative approaches to optimizing physical activity to convert the system of physical education into the European model of education, which implies the students' independent choice of the forms, intensity of classes, convenient schedule, etc. At the same time, the higher education institutions (HEI) of Ukraine create insufficient conditions for the formation of students' need to treat their own health as a socio-biological basis of life, as a necessary point for procreation, as a prerequisite of efficient education and creative work, a guarantee of a perfect gene pool, the foundation of the creativity and spirituality development $[7,8,9]$.

The problem of preserving the health of young students arises in many countries around the world, which are concerned about the intellectual future of the country. It is developed in various scientific publications $[10,11]$. It is conditioned by the fact that over the years of study at HEI, young people do not improve but largely lose the organism reserve capacity that significantly affects their performance. The reason for this is bad habits to a large extent. Because lifestyle directly affects human health, whereas living conditions affect human health indirectly $[12,13]$.

A student who has health disorders and a poor lifestyle cannot fully realize his or her potential physical and intellectual capabilities $[14,15]$. Unfortunately, health does not take the leading position among the needs which are the basis of human behavior, although it should be the main 
Table I. The students' attitude to smoking ( $n=647), \%$

\begin{tabular}{|c|c|c|c|c|c|c|}
\hline \multirow{2}{*}{ Attitude to smoking } & \multirow{2}{*}{ Gender } & \multicolumn{4}{|c|}{ The year of study } & \multirow{2}{*}{$\begin{array}{c}\text { Total } \\
\%\end{array}$} \\
\hline & & $1 \mathrm{st}$ & 2nd & $3 r d$ & 4th & \\
\hline \multirow{3}{*}{ Do not smoke } & males & 63.8 & 57.9 & 54.3 & 55.9 & 59.6 \\
\hline & females & 79.2 & 79.5 & 74.5 & 81.2 & 79.2 \\
\hline & in total & 70.6 & 74.1 & 66.3 & 74.0 & 72.1 \\
\hline \multirow{3}{*}{ Gave up smoking } & males & 6.7 & 9.3 & 5.7 & 8.8 & 8.0 \\
\hline & females & 4.9 & 5.8 & 11.8 & 3.5 & 5.9 \\
\hline & in total & 5.9 & 6.7 & 9.3 & 5.0 & 6.6 \\
\hline \multirow{4}{*}{ Smoke: } & males & 29.5 & 32.8 & 40.0 & 35.3 & 32.4 \\
\hline & females & 15.9 & 14.7 & 13.7 & 15.3 & 14.9 \\
\hline & in total & 23.5 & 19.2 & 24.4 & 21.0 & 21.3 \\
\hline & males & 12.3 & 20.3 & 20.0 & 20.6 & 16.0 \\
\hline up to 10 cigarettes a day & $\begin{array}{c}\text { females } \\
\text { in total }\end{array}$ & $\begin{array}{c}9.8 \\
11.2\end{array}$ & $\begin{array}{c}6.9 \\
10.1\end{array}$ & $\begin{array}{c}9.8 \\
13.9\end{array}$ & $\begin{array}{c}9.4 \\
12.6\end{array}$ & $\begin{array}{c}8.3 \\
11.1\end{array}$ \\
\hline up to 15 cigarettes a day & $\begin{array}{c}\text { males } \\
\text { females }\end{array}$ & $\begin{array}{l}8.6 \\
4.9\end{array}$ & $\begin{array}{l}7.8 \\
7.3\end{array}$ & $\begin{array}{c}20.0 \\
3.9\end{array}$ & $\begin{array}{l}8.8 \\
4.7\end{array}$ & $\begin{array}{c}10.5 \\
5.9\end{array}$ \\
\hline \multirow{4}{*}{ more than 20 cigarettes a day } & in total & 7.0 & 7.5 & 10.5 & 5.9 & 7.6 \\
\hline & males & 8.6 & 4.7 & - & 5.9 & 5.9 \\
\hline & females & 1.2 & 0.5 & - & 1.2 & 0.7 \\
\hline & in total & 5.3 & 1.6 & - & 2.5 & 2.6 \\
\hline
\end{tabular}

Table II. The students' of different educational departments attitude to smoking ( $n=647), \%$

\begin{tabular}{|c|c|c|c|c|}
\hline \multirow{2}{*}{ Attitude to smoking } & \multirow{2}{*}{ Gender } & \multicolumn{3}{|c|}{ Educational departments } \\
\hline & & special & main & sports \\
\hline \multirow{3}{*}{ Do not smoke } & males & 49.1 & 60.4 & 67.8 \\
\hline & females & 79.4 & 78.9 & 80.1 \\
\hline & in total & 68.7 & 72.7 & 74.2 \\
\hline \multirow{3}{*}{ Gave up smoking } & males & 13.2 & 7.1 & 5.1 \\
\hline & females & 7.2 & 6.5 & 1.5 \\
\hline & in total & 9.3 & 6.7 & 3.2 \\
\hline \multirow[t]{3}{*}{ Smoke: } & males & 37.7 & 32.5 & 27.1 \\
\hline & females & 13.4 & 14.6 & 18.4 \\
\hline & in total & 22.0 & 20.6 & 22.6 \\
\hline \multirow[t]{3}{*}{ up to 10 cigarettes a day } & males & 22.6 & 15.1 & 11.9 \\
\hline & females & 5.2 & 9.3 & 9.2 \\
\hline & in total & 11.3 & 11.3 & 10.5 \\
\hline \multirow[t]{3}{*}{ up to 15 cigarettes a day } & males & 15.1 & 8.7 & 10.1 \\
\hline & females & 8.2 & 4.1 & 9.2 \\
\hline & in total & 10.7 & 5.6 & 9.7 \\
\hline \multirow[t]{3}{*}{ more than 20 cigarettes a day } & males & - & 8.7 & 5.1 \\
\hline & females & - & 1.2 & - \\
\hline & in total & - & 3.7 & 2.4 \\
\hline
\end{tabular}

need. A healthy lifestyle is a system of human behavior, which is aimed at constant physical improvement, eating culture, getting rid of bad habits (alcohol, smoking, drugs), etc. $[16,17]$

Therefore, such social phenomena as drug addiction, alcoholism, unwillingness to live without a sense of life, and its devaluation, non-compliance with all other principles of a healthy lifestyle, and maintaining general health are characteristic of a large number of young students today $[18,19,20]$. The scientific data $[21,22]$ show that a significant part of students are quite tolerant of alcohol $(52.3 \%)$, smoking $(34.2 \%)$, drugs $(7.7 \%)$, prostitution $(28.6 \%)$, which means that many students may already have these habits.

\section{THE AIM}

The aim of the study is to investigate the bad habits of the students of higher education institutions and their impact on health.

\section{MATERIALS AND METHODS}

The investigations of the students' bad habits were conducted at Polissia National University (PNU) and Zhytomyr Ivan Franko State University (ZSU) in 2014-2019. 647 students of different specialties between the ages of 17 and 23 were interviewed. Medical examinations were conducted by the doctors of the medical centers of these higher education institutions. 
Table III. The students' attitude to smoking depending on the place of residence ( $n=647), \%$

\begin{tabular}{|c|c|c|c|}
\hline \multirow{2}{*}{ Attitude to smoking } & \multirow{2}{*}{ Gender } & \multicolumn{2}{|c|}{ The place of residence } \\
\hline & & rural areas $(n=341)$ & urban areas $(n=306)$ \\
\hline \multirow{3}{*}{ Do not smoke } & males & 68.5 & 60.2 \\
\hline & females & 84.9 & 74.7 \\
\hline & in total & 78.5 & 69.6 \\
\hline \multirow{3}{*}{ Gave up smoking } & males & 9.2 & 10.2 \\
\hline & females & 4.7 & 7.6 \\
\hline & in total & 6.5 & 8.5 \\
\hline \multirow[t]{3}{*}{ Smoke: } & males & 22.3 & 29.6 \\
\hline & females & 10.4 & 17.7 \\
\hline & in total & 15.0 & 21.9 \\
\hline \multirow[t]{3}{*}{ up to 10 cigarettes a day } & males & 12.3 & 12.0 \\
\hline & females & 6.6 & 8.6 \\
\hline & in total & 8.8 & 9.8 \\
\hline \multirow[t]{3}{*}{ up to 15 cigarettes a day } & males & 7.7 & 10.2 \\
\hline & females & 3.3 & 7.1 \\
\hline & in total & 5.0 & 8.2 \\
\hline \multirow[t]{3}{*}{ more than 20 cigarettes a day } & males & 2.3 & 7.4 \\
\hline & females & 0.5 & 2.0 \\
\hline & in total & 1.2 & 3.9 \\
\hline
\end{tabular}

Table IV. The students' attitude to alcohol ( $n=647), \%$

\begin{tabular}{|c|c|c|c|c|c|c|}
\hline \multirow{2}{*}{ Attitude to alcohol } & \multirow{2}{*}{ Gender } & \multicolumn{4}{|c|}{ The year of study } & \multirow{2}{*}{$\begin{array}{c}\text { Total } \\
\%\end{array}$} \\
\hline & & $1 \mathrm{st}$ & 2nd & 3rd & 4th & \\
\hline \multirow{3}{*}{ Drink regularly, almost every day } & males & 2.9 & 4.7 & - & 2.9 & 2.9 \\
\hline & females & 2.4 & 1.0 & - & - & 1.0 \\
\hline & in total & 2.7 & 2.0 & - & 0.8 & 1.7 \\
\hline \multirow{3}{*}{ Drink 2-3 times a week } & males & 2.9 & 7.8 & 8.6 & 8.8 & 5.9 \\
\hline & females & 1.2 & 3.1 & 2.0 & 2.4 & 2.4 \\
\hline & in total & 2.1 & 4.3 & 4.7 & 4.2 & 3.7 \\
\hline \multirow{3}{*}{ Drink once a week } & males & 27.6 & 20.3 & 40.0 & 17.6 & 26.1 \\
\hline & females & 12.2 & 9.9 & 25.5 & 16.5 & 13.7 \\
\hline & in total & 20.9 & 12.5 & 31.4 & 16.8 & 18.2 \\
\hline \multirow{3}{*}{ Drink only on holidays } & males & 60.9 & 57.8 & 48.5 & 58.9 & 58.0 \\
\hline & females & 70.7 & 72.4 & 66.6 & 69.3 & 70.7 \\
\hline & in total & 65.2 & 68.7 & 59.2 & 66.4 & 66.0 \\
\hline \multirow{3}{*}{ Do not drink at all } & males & 5.7 & 9.4 & 2.9 & 11.8 & 7.1 \\
\hline & females & 13.5 & 13.6 & 5.9 & 11.8 & 12.2 \\
\hline & in total & 9.1 & 12.5 & 4.7 & 11.8 & 10.4 \\
\hline
\end{tabular}

The research methods included theoretical methods (the analysis and generalization of literary sources, the evaluation of the quality of students' performance in classes, the study and analysis of the medical records of students); empirical methods (pedagogical observations, questionnaires, surveys); the methods of mathematical statistics.

This study complies with the ethical standards of the Act of Ukraine "On Higher Education" No. 1556-VII dated 01.07.2014 and the Letter from the Ministry of Education and Science of Ukraine "On the Academic Plagiarism Prevention" No. 1/11-8681 dated 15.08.2018. Also, this study followed the regulations of the World Medical Association Declaration of Helsinki - ethical principles for medical research involving human subjects. Informed consent was received from all individuals who took part in this research.

\section{RESULTS}

The research of the students of PNU and ZSU confirmed that $32.4 \%$ of males and $14.9 \%$ of females smoked. In the first year of study, $29.5 \%$ of males smoked; this number increased significantly in the following years and accounted for $40.0 \%$ in the third year. Among females, first-year students smoked the most (Table I). It is a well-known fact that cigarette smoke is harmful not only to smokers but also to everyone around them. Cigarette smoke contains benzene, which is a source of ionizing radiation. Smoking causes lung cancer, is associated with more than $80 \%$ of chronic bronchitis and lung eczema cases, more than 25 $\%$ of coronary heart diseases, complicates respiratory diseases, gastric ulcers. Smoking is especially dangerous for pregnant women because it leads to the birth of children with low body weight, physical and mental disabilities. 
TableV.Thestudents' of differenteducational departmentsattitudetoalcohol ( $n=647), \%$

\begin{tabular}{|c|c|c|c|c|}
\hline \multirow{2}{*}{ Attitude to alcohol } & \multirow{2}{*}{ Gender } & \multicolumn{3}{|c|}{ Educational departments } \\
\hline & & special & main & sports \\
\hline \multirow{3}{*}{ Drink regularly, almost every day } & males & 1.9 & 2.4 & 5.1 \\
\hline & females & 1.0 & 1.2 & - \\
\hline & in total & 1.3 & 1.6 & 2.4 \\
\hline \multirow{3}{*}{ Drink 2-3 times a week } & males & 1.9 & 7.9 & 5.1 \\
\hline & females & - & 3.3 & 3.1 \\
\hline & in total & 0.7 & 4.8 & 4.0 \\
\hline \multirow{3}{*}{ Drink once a week } & males & 28.3 & 27.0 & 22.0 \\
\hline & females & 18.6 & 11.3 & 15.4 \\
\hline & in total & 22.0 & 16.7 & 18.5 \\
\hline \multirow{3}{*}{ Drink only on holidays } & males & 64.1 & 57.9 & 52.5 \\
\hline & females & 67.0 & 72.9 & 67.7 \\
\hline & in total & 66.0 & 67.8 & 60.6 \\
\hline \multirow{3}{*}{ Do not drink at all } & males & 3.8 & 4.8 & 15.3 \\
\hline & females & 13.4 & 11.3 & 13.8 \\
\hline & in total & 10.0 & 9.1 & 14.5 \\
\hline
\end{tabular}

TableVI.Thestudents' attitude toalcohol depending on the place of residence $(n=647), \%$

\begin{tabular}{|c|c|c|c|}
\hline \multirow{2}{*}{ Attitude to alcohol } & \multirow{2}{*}{ Gender } & \multicolumn{2}{|c|}{ The place of residence } \\
\hline & & rural areas $(n=341)$ & urban areas $(n=306)$ \\
\hline \multirow{3}{*}{ Drink regularly, almost every day } & males & 0.8 & 4.6 \\
\hline & females & 0.5 & 1.5 \\
\hline & in total & 0.6 & 2.6 \\
\hline \multirow{3}{*}{ Drink 2-3 times a week } & males & 4.6 & 9.3 \\
\hline & females & 1.9 & 3.0 \\
\hline & in total & 2.9 & 5.2 \\
\hline \multirow{3}{*}{ Drink once a week } & males & 25.4 & 27.8 \\
\hline & females & 11.8 & 16.7 \\
\hline & in total & 17.0 & 20.6 \\
\hline \multirow{3}{*}{ Drink only on holidays } & males & 64.6 & 49.1 \\
\hline & females & 74.9 & 65.2 \\
\hline & in total & 71.0 & 59.5 \\
\hline \multirow{3}{*}{ Do not drink at all } & males & 4.6 & 9.3 \\
\hline & females & 10.9 & 13.6 \\
\hline & in total & 8.5 & 12.1 \\
\hline
\end{tabular}

Among male students, the students of the special education department smoked the most $-37.7 \%$, followed by the students of the main department $-32.5 \%$ and the sports department $-27.1 \%$. The females had the opposite trend: $18.4 \%$ of female students of the sports education department, $14.6 \%$ of the main education department, and $13.4 \%$ of the special education department smoked (Table II). A negative example for the students of the sports department is smoking among teachers, coaches, judges, organizers of sports events and the most authoritative sportsmen in teams, there is also a wrong idea that smoking has a positive effect on reducing excess weight.

Another characteristic feature defined was that the students from rural areas smoked less $-15.0 \%(22.3 \%-$ males and $10.4 \%$-females), in comparison with $29.6 \%$ of males and $17.7 \%$ of females from urban areas (Table III).

Alcohol consumption is quite common among students.
The study identified that in the first year of study, $2.7 \%$ of students drank alcohol almost every day, 3.7 \% - 2-3 times a week, $18.2 \%$ - once a week, $66.0 \%$ - only on holidays (Table IV). Among young students, only $7.1 \%$ of males and $12.2 \%$ of females did not drink alcohol at all.

The research indicated that the work with students concerning the harmful effects of alcohol consumption on sports performance and health was insufficient. The obtained data showed that only $15.3 \%$ of males and $13.8 \%$ of females of the sports departments did not drink alcohol at all. It was found that $2.4 \%$ of the sports department students drank alcohol regularly, $4.0 \%$ - two or three times a week, $18.5 \%$ - once a week (Table V). The students of the sports departments usually have larger areas of communication with their peers; attend training meetings and competitions with no control by parents and teachers, so they follow negative life examples, including smoking, alcohol, drugs, etc. very often. 
Table VII. The reasons that encourage students to drink alcohol ( $n=647), \%$

\begin{tabular}{|c|c|c|c|c|c|c|}
\hline \multirow{2}{*}{ The reasons } & \multirow{2}{*}{ Gender } & \multicolumn{4}{|c|}{ The year of study } & \multirow{2}{*}{$\begin{array}{c}\text { Total } \\
\%\end{array}$} \\
\hline & & $1 \mathrm{st}$ & 2nd & 3rd & 4th & \\
\hline \multirow{3}{*}{ Resting in company } & males & 35.2 & 46.9 & 51.4 & 47.1 & 42.4 \\
\hline & females & 37.8 & 38.7 & 39.2 & 43.5 & 39.6 \\
\hline & in total & 36.4 & 40.8 & 44.2 & 44.5 & 40.6 \\
\hline \multirow{3}{*}{ Meeting with friends } & males & 33.3 & 46.9 & 37.1 & 23.5 & 36.1 \\
\hline & females & 34.1 & 32.5 & 31.4 & 27.1 & 31.5 \\
\hline & in total & 33.7 & 36.1 & 33.7 & 26.1 & 33.2 \\
\hline \multirow{3}{*}{ The desire to relax } & males & 13.3 & 4.7 & 17.1 & 8.8 & 10.9 \\
\hline & females & 11.0 & 6.8 & 7.8 & 1.2 & 7.8 \\
\hline & in total & 12.3 & 6.3 & 11.6 & 7.6 & 9.0 \\
\hline \multirow{3}{*}{ Boredom } & males & 8.6 & 1.6 & 8.6 & 8.8 & 6.7 \\
\hline & females & 6.1 & 2.6 & - & 2.4 & 2.7 \\
\hline & in total & 7.5 & 2.4 & 3.5 & 3.4 & 4.2 \\
\hline \multirow{3}{*}{ Meeting with parents } & males & 2.9 & 1.6 & - & 2.9 & 2.1 \\
\hline & females & - & 1.0 & 2.0 & 1.2 & 1.0 \\
\hline & in total & 1.6 & 1.2 & 1.2 & 1.7 & 1.4 \\
\hline \multirow{3}{*}{ Do not have such need } & males & 41.0 & 37.5 & 25.7 & 32.4 & 36.6 \\
\hline & females & 40.2 & 40.8 & 43.1 & 41.2 & 41.1 \\
\hline & in total & 40.6 & 40.0 & 36.0 & 38.7 & 39.4 \\
\hline
\end{tabular}

Table VIII. The subjective assessment of the students' attitudes to drug use ( $n=647), \%$

\begin{tabular}{|c|c|c|c|c|c|c|}
\hline \multirow{2}{*}{ The subjective assessment } & \multirow{2}{*}{ Gender } & \multicolumn{4}{|c|}{ The year of study } & \multirow{2}{*}{$\begin{array}{c}\text { Total } \\
\%\end{array}$} \\
\hline & & $1 \mathrm{st}$ & 2nd & $3 r d$ & 4th & \\
\hline \multirow{3}{*}{ Use drugs } & males & 2.9 & - & - & - & 1.3 \\
\hline & females & - & 0.5 & 2.0 & 2.4 & 1.0 \\
\hline & in total & 1.6 & 0.4 & 1.2 & 1.7 & 1.1 \\
\hline \multirow{3}{*}{ Tried drugs } & males & 4.8 & 3.1 & 2.9 & 17.6 & 5.9 \\
\hline & females & 1.2 & 1.6 & 7.8 & 2.4 & 2.2 \\
\hline & in total & 3.2 & 2.0 & 5.8 & 6.7 & 3.6 \\
\hline \multirow{3}{*}{ Do not use drugs } & males & 92.3 & 96.9 & 97.1 & 82.4 & 92.8 \\
\hline & females & 98.8 & 97.9 & 90.2 & 95.2 & 96.8 \\
\hline & in total & 95.2 & 97.6 & 93.0 & 91.6 & 95.3 \\
\hline \multirow{3}{*}{ Know drug effects } & males & 3.8 & 9.4 & 11.4 & 2.9 & 6.3 \\
\hline & females & - & 2.1 & 9.8 & 1.2 & 2.4 \\
\hline & in total & 2.1 & 3.9 & 10.5 & 1.7 & 3.7 \\
\hline \multirow{3}{*}{ Do not know drug effects } & males & 96.2 & 90.6 & 88.6 & 97.1 & 93.7 \\
\hline & females & 100 & 97.9 & 90.2 & 98.8 & 97.6 \\
\hline & in total & 97.9 & 96.1 & 89.5 & 98.3 & 96.3 \\
\hline
\end{tabular}

It should also be noted that students from urban areas are more prone to alcohol consumption. Thus, it was determined that $2.6 \%$ of students from urban areas and $0.6 \%$ of students from rural areas drank alcohol regularly; 5.2 and $2.9 \%$ - two or three times a week respectively; 20.6 and $17.0 \%$ - once a week respectively (Table VI).

The main reasons defined that encourage students to drink alcohol were resting in a company (40.6\%), meeting with friends $(33.2 \%)$, the desire to relax $(9.0 \%)$, boredom $(4.2 \%)$, meeting with parents $(1.4 \%)$. Only $39.4 \%$ of students did not feel the need to drink alcohol for their leisure and recreation (Table VII). The research showed that students were involved in alcohol consumption not in families but communicating with their peers while watching movies, attending various parties, discos, of- fering alcoholic beverages with exotic names and bright advertising.

According to scientists [23], blood does not retain alcohol, it is accumulated in the cells of the central nervous system, liver, and heart. The breakdown products of alcohol can stay in these organs from 13 to 15 days. The repeated use of alcohol makes it even longer. The frequent alcohol consumption involves it in muscle metabolism and alcohol becomes its constant participant, especially in brain tissue. The first signs of chronic alcoholism are a strong craving for alcohol, increased endurance to alcohol, and a hangover. Severe alcohol intoxication kills about 20,000 nerve cells. Alcohol abuse is one of the leading causes of death directly and indirectly, especially for men of working age. According to the WHO, the 
mortality rate among alcohol abusers is 2-4 times higher than among the general population [24].

Unfortunately, some young students also use drugs. The male students of the first year of study were found to use drugs, in contrast to the students of the 2 nd -4 th years. This fact gives grounds to claim that they had already used drugs before entering HEI. The second-year female students were also involved in drug consumption, the number of which accounted for $2.4 \%$ in the 4 th year of study (Table VIII). The obtained data showed that $4.7 \%$ of students used or tried drugs, $3.7 \%$ certainly knew their effects, which also indicated that students used or tried drugs and experienced their effects.

In addition to the above-mentioned negative factors affecting the health of young people, there is also the use of psychotropic substances, which are not classified as narcotic but form a drug addiction and make a young person drug-addicted quickly. Drug addiction and substance abuse, as well as alcoholism, are characterized by three main features: mental and physical dependence on narcotic and toxic substances, as well as addiction to them. Alcoholism develops these symptoms gradually, whereas toxic substances and drug addiction - extremely quickly. Physical dependence is the patient's condition, which is characterized by intense physical and mental disorders if the substances consumption is stopped. An injection of a toxic drug can alleviate these disorders.

An intake of toxic substances through the respiratory system is one of the most dangerous ways because in addition to the general toxic effects on the whole body, they have a destructive influence on the cells of the bronchial epithelium. This leads to inflammation of the respiratory system. Besides, toxic substances have a dangerous impact on the cardiovascular system, metabolic processes, liver, central nervous system, etc. The consumption of drugs and toxic substances causes a degradation of personality, reduces intellectual abilities, leads to physical and mental exhaustion, emotional imbalance, the loss of moral attitudes and values. It should also be noted that new temptations have become widespread for young people recently, including gambling, Internet addiction, loss of volitional behavior, which have a significant negative impact on the health and general life of students.

\section{DISCUSSION}

Nowadays, there are large number of diseases, which are directly conditioned by the imbalance of the actual needs of the individual and anthropogenic needs. Anthropogenic needs are considered to be the needs arising from human nature, a man as a biosocial phenomenon. Anthropogenic needs do not include the need for tobacco, alcohol, drugs, toxic substances, etc. The contradictions between the needs that a person creates in the process of life and those that are necessary and sufficient for the life and development often lead to infectious diseases, heart attack, insult, cancer and a whole range of socio-psychological imbalances $[25,26]$.
The main anthropogenic need is the need for life. The system of human needs distinguishes three main groups of anthropogenic needs [27, 28, 29]:

1. Vital needs ("existence") are a state of the human body caused by the internal imbalance of metabolism and homeostasis with changing constants of the internal environment, and biological imbalance with the external world. At the biological level, this group includes the following needs: food, water, air, light, temperature and climate, sexual partner, self-preservation, etc. At the social level, these are the needs for clothing, family, and housing. It also includes sanitary, household, and environmental needs..

2. Emotional needs ("satisfaction") are a certain state of mind caused by unsatisfied emotional attitudes to objects and phenomena of the world. The basis of emotional needs are the emotional states, which are revealed as feelings (aesthetic and communicative needs, the need for love and friendship).

3. Rational needs ("improvement") are controlled and maintained by volitional powers. They are aimed at achieving a conscious personal or social goal (educational, cognitive, intellectual, aesthetic, legal, self-improving, etc.).

Thus, the paper reveals the impact of bad habits and health needs on the HEI students' health. It proved that smoking, alcohol, drugs, and various destructive health practices are widespread among young students. The study found that very few health technologies are currently being introduced in the student environment.

Obviously, such alarming affairs require supplementing the system of measures to eliminate students' badhabits through physical education. This can be facilitated by the involvement of young students in independent physical exercises, sports, tourism, interesting leisure, etc. In order to make a person change one's way of life, the measures that would touch one's consciousness should be taken. This encourages a change in behavior, getting rid of addictions. The mostefficient means of influencing consciousness are interactive technologies, i.e. those that influence several human signaling systems. Interactive technologies include modern video technologies with the use of computer programs - websites, video films, activating the need for a healthy lifestyle, the desire for beauty, harmony, preservation of life [30]. In addition, it is necessary to strengthen educational work and advocacy of the importance of a healthy lifestyle among young students, to create clubs for interesting leisure, to expand sports and cultural events, and introduce incentives for a healthy lifestyle. Therefore, in order to meet all needs, there must be a high standard of living, and it is not possible without a sufficient level of health. Poor health is characterized by reduced defenses and the body's resistance to the negative effects of the environment, which leads to disease. Diseases cause disorders of homeostasis, i. e. changes in much of the parameters of the internal environment, which leads to discomfort, and ultimately to pain and suffering. Thus, there is a chain reaction of interrelated changes, the initial link of which is homeostasis disorders, and the final - painful sensations. The changes in homeostasis are the primary link, a trigger for various functional issues caused by the 
Table IX. The indicators of students' compliance with sleeping schedule ( $n=647), \%$

\begin{tabular}{|c|c|c|c|c|c|c|}
\hline \multirow{2}{*}{ Sleep duration } & \multirow{2}{*}{ Gender } & \multicolumn{4}{|c|}{ The year of study } & \multirow{2}{*}{$\begin{array}{c}\text { Total } \\
\%\end{array}$} \\
\hline & & 1st & 2nd & $3 r d$ & 4th & \\
\hline \multirow{3}{*}{ Less than 7 hours } & males & 22.9 & 34.4 & 17.1 & 14.7 & 23.9 \\
\hline & females & 20.7 & 19.9 & 13.7 & 25.9 & 20.5 \\
\hline & in total & 21.9 & 23.5 & 15.1 & 22.7 & 21.8 \\
\hline \multirow{3}{*}{$7-8$ hours } & males & 61.0 & 54.7 & 65.8 & 61.8 & 60.1 \\
\hline & females & 51.2 & 69.6 & 76.5 & 58.8 & 64.6 \\
\hline & in total & 56.7 & 65.9 & 72.1 & 59.7 & 62.9 \\
\hline \multirow{3}{*}{ More than 8 hours } & males & 16.1 & 10.9 & 17.1 & 23.5 & 16.0 \\
\hline & females & 28.1 & 10.5 & 9.8 & 15.3 & 14.9 \\
\hline & in total & 21.4 & 10.6 & 12.8 & 17.6 & 15.3 \\
\hline
\end{tabular}

Table X. The students' compliance with sleep schedule ( $n=647), \%$

\begin{tabular}{|c|c|c|c|c|c|c|}
\hline \multirow{2}{*}{ Go to bed } & \multirow{2}{*}{ Gender } & \multicolumn{4}{|c|}{ The year of study } & \multirow{2}{*}{$\begin{array}{c}\text { Total } \\
\%\end{array}$} \\
\hline & & $1 \mathrm{st}$ & 2nd & 3 rd & 4th & \\
\hline \multirow{3}{*}{ Before 10 p.m. } & males & 3.8 & 3.1 & - & 8.9 & 3.8 \\
\hline & females & 9.8 & 6.8 & 3.9 & 9.4 & 7.6 \\
\hline & in total & 6.4 & 5.9 & 2.3 & 9.2 & 6.2 \\
\hline \multirow{3}{*}{ After 10:30 p.m. } & males & 16.2 & 15.6 & 31.4 & 17.6 & 18.5 \\
\hline & females & 31.7 & 29.3 & 33.3 & 28.2 & 30.0 \\
\hline & in total & 23.0 & 25.9 & 32.6 & 25.2 & 25.8 \\
\hline \multirow{3}{*}{ After 11 p.m. } & males & 52.4 & 42.2 & 42.9 & 55.9 & 48.7 \\
\hline & females & 34.1 & 47.1 & 51.0 & 38.8 & 43.4 \\
\hline & in total & 44.4 & 45.8 & 47.7 & 43.8 & 45.3 \\
\hline \multirow{3}{*}{ After the midnight } & males & 27.6 & 39.1 & 25.7 & 17.6 & 29.0 \\
\hline & females & 24.4 & 16.8 & 11.8 & 23.5 & 19.0 \\
\hline & in total & 26.2 & 22.4 & 17.4 & 21.8 & 22.7 \\
\hline
\end{tabular}

disease. The temperature rise, increased heart rate, rapid breathing, muscle weakness and apathy, changes in blood pressure and blood composition are secondary changes aimed at neutralizing disorders of homeostasis. According to the mechanism of their origin and the orientation, these changes have a protective character. All these changes are accompanied by a deterioration of the emotional state. The research of homeostasis and reactions aimed at compensating for its disorders, it is established that homeostasis, functional capabilities of the organism, well-being and quality of life are closely related [25, 31].

The scientists $[32,33]$ note that the body is arranged in such a way that the changes in any organ cause changes in the parameters of other organs. These secondary changes are aimed at compensating for changes in homeostasis and stabilize the internal environment of the organism. Thus, the organism seeks to restore the impaired quality of life. The most common example of such recovery is a good sleep after a hard day. During sleep there the spent energy potential of an organism is restored, numerous changes in a metabolism caused by physical and mental activity occur. As a result, homeostasis is stabilized, which is revealed in improved well-being, the restoration of working capacity and health.

Therefore, compliance with sleeping schedule is one of the most important needs, which can significantly influence the efficiency and well-being of a student throughout the day. At the same time, research showed that $21.8 \%$ of students slept less than 7 hours that did not meet daily needs. A significant part $(15.3 \%)$ of students spent more than 8 hours on sleep (Table IX).

The analysis of students' sleep schedule showed that most students did not follow a daily routine at all. A rational daily routine creates optimal conditions for the activity and recovery of the body and helps to increase physical and mental performance. It is conditioned by the fact that the correct and clear daily routine creates a certain rhythm of the organism activity; as a result, a student can perform various types of work most effectively at a certain time. Strict compliance with the daily routine is also a good means of developing organization, independence, will and it teaches a conscious discipline.

The scientists $[8,20]$ note that owing to different living, working and studying conditions, household and individual characteristics, there can be no single daily routine for everyone. But the basic provisions must be followed in any case. First, the student's daily routine should provide the performance of various kinds of activity in precisely defined time; the correct alternation of educational activities, physical exercises and rest; regular meals at the same time; the optimal time for preparing homework and physical training; long and good quality sleep. If a student does not go to bed on time, one can not get up early and start his/her day efficiently. Table X shows that $6.2 \%$ of 
students went to bed before 10 p.m., $25.8 \%$ - after 10:30 p.m., $45.3 \%$ - after 11 p.m., $22.7 \%$ - after the midnight. The number of the students' sleep hours is also affected by the distance of their place of residence from the HEI, the amount of time spent on the way, breakfast, etc.

That is why the introductory physical education classes, especially for first-year students, should pay attention to the organization of the daily routine, help students navigate new circumstances, plan their time according to actual living conditions in the following way: morning toilet (gymnastics, shower(wash), personal body care); breakfast (withouthaste); studying, andrecovery activities if possible in the morning; lunch followed by a break; mental work (in the library, at home, laboratories, etc.); exercises or sports (followed by active recovery procedures); dinner (easily digestible food); free time; sleep (sufficient) [34].

It is necessary to accustom organism to a certain system: to get up and go to bed at the same time; to work out from 5 to $7 \mathrm{p} . \mathrm{m}$. This will lead to a physiologically correct mode of higher nervous activity and promote the development of certain behavior reflexes. As a result, it makes it possible to achieve a balance between the organism and the environment [8].

At the same time, many scientists [29, 31] claim that living in unfavorable hygienic conditions, without following a rational daily routine, personal hygiene rules leads to poor health and a sharp deterioration of health. The student's personal hygiene includes a wide range of issues related to a rational daily routine, body and dental care, compliance with the hygienic conditions of study and life, etc. The knowledge of the rules of personal hygiene is necessary for every student. This is especially important for student-athletes because strict compliance with these rules helps to improve health, increase the efficiency of training. Body care includes hygienic procedures for skin, hands, feet, mouth care, etc.

Almost every student experienced situations of homeostasis disorders associated with pain and activity restrictions. Even a light angina or cold cause discomfort or pain. Of course, a sore throat caused by inflammation and swelling in the tonsils is unpleasant. The students attribute the reason for the decline in quality of life to it. However, neither this pain nor the inflammatory process in the lymph glands, nor the temperature rise is the cause of the disease. These phenomena are the body's response to an adverse situation that has arisen because of disease-causing microbes. In most cases, such phenomena occur as a result of increased activity of microbial flora because of a decrease in protective forces that can be caused by stress, bad habits, etc. [32]

The next health-improving issue for the students' productive life that experts $[10,13,35]$ advice is the elimination of various excesses in the organism. These are accumulated substances that become a burden or pathogen for the organism, the conditions or processes that go beyond the norm and worsen the body's vitality. The most typical example is overweight or obesity. There are two types of fat: intracellular, which is a mandatory component of the pro- toplasm of human cells, and extracellular. A small amount of extracellular fat should be placed in a thin layer (up to 2-3 mm) under the skin. The value of body fat is beyond doubt. However, an increased amount of extracellular fat in the organism creates a number of factors that negatively affect the viability of students, significantly reducing their health. An excessive amount of fat in the organism makes a person not energetic and tired, causes headaches, depression. The studies show that there is a link between obesity and health problems. Overweight people are more likely to have circulatory diseases, malignant tumors, diabetes. There is a relationship between the amount of excess fat in the organism and reduced life expectancy [25, 31].

An important reserve for updating the educational process is applying health technologies in the process of physical education, the introduction of which will provide students with knowledge, skills, and abilities to manage individual health, to deal with bad habits, and prepare them for highly qualified professional activities.

\section{CONCLUSIONS}

1. The compliance with the regime of study and rest, nutrition, sleep, regular exercise helps to get rid of bad habits, which are usually accompanied by an inert state, reduced efficiency and reaction speed. At the same time, the system of education at HEI does not form a proper motivation for a healthy lifestyle. Most students know that smoking, alcohol, and drugs are bad but they can't or don't want to get rid of those bad habits. The viability and health of students largely depend on the student's behavior, which forms emotions that influence metabolism and energy, which provides a flow of non-specific (from the physical environment) and specific (from social conditions) information. All these influences significantly change the objective basis of health - viability. Forming various functional states of the organism, the students' behavior dramatically changes the potential of health.

2. The problem of health formation is becoming an important component of almost all modern pedagogical innovative technologies. Toensure efficientcooperation between teachers and students, health should be considered as a means of daily life, as a positive part of life, emphasizing social and personal resources, as well as the physical capabilities of each student. It was found that the environment of students is unfavorable for the activation of the healthy lifestyle components; it contributes to the spread of bad habits, the consequences of which students do not realize. Many students do not have a need to take care of their own health. Such students rely on their youth, the activities of medical institutions, and neglect such efficient and cost-effective means of rehabilitation as physical culture and sports.

\section{REFERENCES}

1. Gruzieva T., Galiienko L., Pelo I. et al. Health and lifestyle of students' youth: status, problems and ways of solution. Wiad Lek. 2018; 71(9): 1753-1758. 
2. ProntenkoK.,GribanG.,AloshynaA. etal.Thephysical developmentand functional state as the important components of the students' health. Wiad. Lek. 2019; 72 (12a): 2348-2353. doi: 10.36740/WLek201912115.

3. Mozolev 0., Bloshchynsky I., Alieksieiev 0. et al. Influence of modern fitness technologies on the state of health and development of motor abilities of 17-19-year-old female students. Journal of Physical Education and Sport. 2019; 19(Supplement issue 3): 917-924. doi:10.7752/jpes.2019.s3132.

4. Prontenko K., Griban G., Dovgan N. et al. Students' health and its interrelation with physical fitness level. Sport Mont. 2019; 17(3): 41-46. doi 10.26773/smj.191018.

5. Griban G., Prontenko K., Zhamardiy V. et al. Professional stages of a physical education teacher as determined using fitness technologies. Journal of Physical Education and Sport. 2018; 18(2): 565-569. doi:10.7752/jpes.2018.02082.

6. Leuciuc F. Perception on physical education among students. Revista Romaneasca pentru Educatie Multidimensionala. 2018; 10(2): 134-143. doi:https://doi.org/10.18662/rrem/51.

7. Kharchenko O., Kharchenko N.,Shaparenkol.,Sakharova L. Analysis of thephysical development of youthand thestate of its health. Wiad Lek. 2019; 72(4): 575-578.

8. Griban G. P.Zhyttiediialnist ta rukhova aktyvniststudentiv [Lifeactivity and mobility of students]. Zhytomyr: Ruta; 2009: 594 . (in Ukrainian).

9. Prontenko K., Bloshchynskyi l., Griban G. et al. Formation of readiness of future physical culture teachers for professional activity. Universal Journal of Educational Research. 2019; 7(9): 1860-1868. doi: 10.13189/ ujer.2019.070903.

10. Warburton D., Nicol C. W., Bredin S. S. D. Health benefits of physical activity: the evidence. Canadian Medical Association Journal. 2006; 174: 801-809.

11. Kosiba G., Gacek M., Wojtowicz A., Majer M. Level of knowledge regarding health as well as health education and pro-health behaviours among students of physical education and other teaching specializations. Baltic Journal of Health and Physical Activity. 2019; 11(1): 83-95. doi: 10.29359/BJHPA.11.1.09

12. Makarov S., Stoyan N., Serheta I., Taran O., Dyakova O. Peculiarities of the interaction of the indicators of psychophysiological adaptation of modern students in the context of the effective monitoring of individual health of young women and young men. Wiad. Lek. 2019; 72 (5a): 1053-1058.

13. Bolotin A., Bakayev V. Structure and content of the educational technology of managing students' healthy lifestyle. Journal of Physical Education and Sport. 2015; 15(3): 362-364. doi:10.7752/ jpes.2015.03054.

14. ApanasenkoG. L. Knygha ozdorovj'e[Health Book]. Kyev: Medknygha; 2007: 132 . (in Russian).

15. Vilenskiy M.Ya. Sotsialno-psihologicheskie determinantyi formirovaniya zdorovogo obraza zhizni [Socio-psychological determinants of a healthy lifestyle].Teoriyai praktika fizicheskoykulturyi.1994; 9:9-11. (in Russian).

16. Budagh'janc Gh.M. Zdorovyj sposib zhyttja - osnovna umova profilaktyky deviantnoji povedinky pidlitka (istorychnyj aspekt) [Healthy lifestyle - the mainconditionforthe prevention ofadolescentdeviantbehavior(historical aspect)]. Pedaghoghika, psykhologhija ta medyko-biologhichni problemy fizychnoghovykhovannjaisportu. 2010; 6:25-28. (in Ukrainian).

17. Muntjan V.S. Analyz faktorov, opredeljajushhykh zdorovj'e cheloveka y okazyvajushhykhnaneghovlyjanyja[Analysis offactorsthat determine human health and influence it]. Fyzycheskoe vospytanye studentov. 2010; 6: 44-47. (in Russian).
18. Duboghaj 0.D., Aljoshyna A.I., Lavrynjuk V.Je. Osnovni ponjattja i terminy zdorov'jazberezhennja ta fizychnoji reabilitacijiv systemi osvity [Basic concepts and terms of healthcare and physical rehabilitation in the education system]. Lucjk: Volynsjkyj nacionaljnyj universytet imeni Lesi Ukrajinky; 2011; 296. (in Ukrainian).

19. GribanG.,TymoshenkoO.,ArefievV.etal.Theroleof physical education in improving the health status of students of special medical groups. Wiad. Lek. 2020; 73 (3): 534-540. doi: 10.36740/WLek202003125.

20. VoytenkoV.P.Zdorovezdorovyih [Healthyhealth].Zdorov'ya.1991:248. (in Russian).

21. Malimon 0., Volchinskiy A. Dinamika zahvoryuvanosti ta stanu zdorov'ya studentiv [Dynamics of student morbidity and health]. Fizichne vihovannya, sport i kultura zdorov'ya u suchasnomu suspilstvi. 2005; 1: 286-289. (in Ukrainian).

22. Amini M., Mehraban A. H., Haghani H., Mollazade E., Zaree M. Factor structure and construct validity of children participation assessment scale in activities outside of school-parent version (CPAS-P). OccupationalTherapyin Health Care. 2017;31(1),44-60. doi:10.1080/ 07380577.2016.1272733.

23. Ciubara A., Burlea Ş., Săcuiul., et al. Alcohol addiction-a psychosocial perspective. Procedia-Social and Behavioral Sciences. 2015; 187, 536540. doi:10.1016/j.sbspro.2015.03.100.

24. World Health Organization. Global recommendations on physical activity for health. 2015. http://www.who.int/dietphysicalactivity/ factsheet_recommendations.

25. Bulych E.Gh., Muravov Y.V.Zdorovje cheloveka: Byologhycheskaja osnova zhyznedejateljnosty y dvyghateljnaja aktyvnostj v ee stymuljacyy [Human health: the biological basis of vital activity and motor activity in its stimulation]. Olympic Literature. 2002; 424. (in Russian).

26. Maglovanyi A.V. Osnovy informacijnogho polja zdorov'ja osobystosti [Basics of information field of personality health]. Visnyk Chernighivsjkogho nacionaljnogho pedaghoghichnogho universytetu imeni T. Gh. Shevchenka. Serija: Pedaghoghichni nauky. Fizychne vykhovannja ta sport. 2010;81:285-289. (in Ukrainian).

27. Zavydivska O., Zavydivska N., Khanikiants O. Self-management as a condition for creating a health culture among students. Journal of Physical Education and Sport. 2016; 16(1): 592-597. doi:10.7752/ jpes.2016.s1093.

28. Prontenko K., Griban G., Bloshchynskyi I. et al. Improvement of students'morpho-functional development and health in the process of sport-oriented physical education. Wiad Lek. 2020; 73(1): 1753-1758. doi: 10.36740/WLek202001131.

29. Apanasenko G., Dolzhenko L. Rivenj zdorov'ja i fiziologhichni rezervy orghanizmu. [The level of health and physiological reserves of the organism].Teorijaimetodyka fizychnogho vykhovannja isportu. 2007; 1: 17-21. (in Ukrainian).

30. ZhamardiyV.,Shkola O.,Okhrimenkol.etal.Checking ofthe methodical system efficiency of fitness technologies application in students' physical education. Wiad Lek. 2020; 73 (2), 332-341. doi: 10.36740/ WLek202002125.

31. Paffenbarger R.S., Olsen E. Zdorovyiy obraz zhizni [Healthy lifestyle]. Olympic Literature. 1999: 320. (in Russian).

32. VaynerE. N.Valeologiya[Valeology]."Flinta”,"Nauka”.2001:416. (inRussian).

33. Ghoncharenko M.S., Novykova V.Je. Valeologhichni aspekty formuvannja zdorov'ja u suchasnomu osvitjansjkomu procesi [Valeology aspects of the formation of health in the modern educational process]. Pedaghoghika, psykhologhija ta metodyko-biologhichni problemy fizychnoghovykhovannjaisportu. 2010; 6:45-51. (in Ukrainian). 
34. Krutsevych T.Yu. Teoriia i metodyka fizychnoho vykhovannia [Theory and methods ofphysicaleducation]: pidruchnykdliastud. vuzivfiz.vykhov. isportu.T.1.Zahalniosnovyteoriiimetodykyfizychnohovykhovannia. Olympic Literature. 2008: 391. (in Ukrainian).

35. Futornyj S.M. Dvyghateljnaja aktyvnostj y ee vlyjanye na zdorovj'ey prodolzhyteljnostj zhyzny cheloveka [Motor activity and its effect on human health and longevity]. Fyzycheskoe vospytanye studentov. 2011; 4: 79-84. (in Russian).

The work was carried out according to the plan of the research work of Zhytomyr Ivan Franko State University and University for 2014-2024 on the theme of "Theoretical and methodological bases of improving the educational process of physical education at higher educational institutions" (state registration number 0114U003978).

\section{ORCID and contributionship:}

Grygoriy P. Griban: 0000-0002-9049-1485 A, D

Mykhailo S. Myroshnychenko: 0000-0002-6920-8374 B, E

Pavlo P. Tkachenko: 0000-0003-4407-8611 A

Tetiana Ye. Yavorska: 0000-0001-6104-2202 C

Nataliia Ye. Kolesnyk: 0000-0001-9384-9369 F

Inesa V. Novitska: 0000-0003-0780-0580 E

Igor A. Verbovskyi: 0000-0001-7202-3429 D

\section{Conflict of interest:}

The Authors declare no conflict of interest.

\section{CORRESPONDING AUTHOR}

\section{Grygoriy P. Griban}

Zhytomyr Ivan Franko State University

40 V. Berdychivska St., 10002 Zhytomyr, Ukraine

tel: +380973341092

e-mail: gribang@ukr.net

Received: 12.07 .2020

Accepted: 01.10.2020 